\title{
РЕГІОНАЛЬНІ ОСОБЛИВОСТІ ВИЇЗНОГО ТУРИЗМУ В УКРАÏHI
}

\section{REGIONAL FEATURES OF OUTBOUND TOURISM IN UKRAINE}

\author{
Тарасова Валентина Віталіївна \\ доктор економічних наук, профресор, \\ Поліський національний університет \\ ORCID: https://orcid.org/0000-0003-1275-9666 \\ Ковалевська Ірина Миколаївна \\ кандидат економічних наук, \\ Поліський національний університет \\ ORCID: https://orcid.org/0000-0001-9356-4531
Tarasova Valentyna, Kovalevska Iryna
Polissya National University

\begin{abstract}
У статті розкрито стан і тенденції розвитку туристичної галузі в Україні та динамічного розвитку її специфрічного виду - виїзного туризму. Охарактеризовано динаміку туристичних потоків громадян України, що виїжджали за кордон. Досліджено склад зарубіжних країн, до яких виїжджали з різною метою громадяни України. Розглянуто зональні особливості фрормування туристичних потоків, а також Європейські й Азійські головні світові регіони паломництва. Туризм, у сучасних умовах, є вкрай динамічним як на вітчизняному, так i на міжнародному туристичних ринках. В Україні тільки за останні декілька років значно збільшилася кількість туристів, що здійснюють закордонні поїздки, а також прямують за кордон з релігійно-пізнавальними цілями. Завданням статті було дослідження сучасного стану і тенденцій розвитку туристичних потоків і окремих видів туризму в Україні: виявлення мети виїзду громадян України за кордон та географії їх поїздок.

Ключові слова: туристичні потоки, в'їзні потоки, виїзні потоки, внутрішні потоки, пострадянські країни, країни ближнього зарубіжжя, країни дальнього зарубіжжя.
\end{abstract}

В статье раскрыто состояние и тенденции развития туристической отрасли в Украине и динамичного развития ее специфического вида - выездного туризма. Охарактеризована динамика туристических потоков граждан Украины, которые выезжали за границу. Исследован состав зарубежных стран, в которые выезжали с разной целью граждане Украины. Рассмотрены зональные особенности фрормирования туристических потоков, а также Европейские и Азиатские главные мировые регионы паломничества. Туризм, в современных условиях, является крайне динамичным как на отечественном, так и на международном туристических рынках. В Украине только за последние несколько лет значительно увеличилось количество туристов, совершающих зарубежные поездки. а также направляются за границу с религиозно-познавательными целями. Задачей статьи было исследование современного состояния и тенденций развития туристических потоков и отдельных видов туризма в Украине: выявление цели выезда граждан Украины за границу и географии их поездок.

Ключевые слова: туристические потоки, въездные потоки, выездные потоки, внутренние потоки, постсоветские страны, страны ближнего зарубежья, страны дальнего зарубежья.

The article reveals the state and trends of development of the tourism industry in Ukraine and the dynamic development of its specific type - outbound tourism. The dynamics of tourist flows of Ukrainian citizens traveling abroad is characterized. The composition of foreign countries to which citizens of Ukraine travelled for different purposes was studied. The zonal features of the formation of tourist flows and the European and Asian main world regions of pilgrimage are considered. Tourism, in modern conditions, is extremely dynamic in both domestic and international tourism markets. In Ukraine only in the last few years, the number of tourists traveling abroad and traveling abroad for religious and educational purposes has increased significantly. The main routes of such trips were to Israel, Italy, Greece, Cyprus, Turkey, Egypt, Saudi Arabia. The purpose of the article is a comprehensive description of the development of various aspects and types of tourism and the regional features of its development in Ukraine. The goal of the article was to study the current state and trends in the development of tourist flows and certain types 
of tourism in Ukraine: to identify the purpose of departure of Ukrainian citizens abroad and the geography of their trips. Every year many tourists visit Ukraine and their number is constantly growing. Trends in the development of certain types of tourism are multidirectional: the number of outbound tourists is growing rapidly, domestic - is significantly reduced, inbound - is slowly declining. The total number of all tourists in Ukraine changes cyclically, having five-year cycles with peaks in $2003,2008,2013$. Due to outbound tourists there is a sharp rise in the total number of tourists - 1.6 times in 2018 and 2.2 times in 2019. The structural composition of tourists is not homogeneous: it has flows of domestic, incoming and outgoing tourists, which is very different in the areas of Ukraine. The basis of foreign trips are tourists from post-Soviet countries and the neighbor countries. Russia is the most popular among post-Soviet countries, Poland among neighbor countries, and Italy among foreign countries (30\%). The purpose of travel of Ukrainian citizens abroad is different, the main ones are: private and business trips and organized tourism. The geography of foreign routes covered all countries of Europe and the Middle East.

Keywords: tourist flows, inbound flows, outbound flows, domestic flows, post-Soviet countries, neighbor countries, foreign countries.

Постановка проблеми. Значення туристичної індустрії з кожним роком зростає. Люди всього світу все частіше обирають екскурсійні тури по популярним, найбільш шанованим і відвідуваним місцям та релігійним об'єктам. Туризм, у сучасних умовах, є вкрай динамічним як на вітчизняному, так і на міжнародному туристичних ринках. В Україні тільки за останні декілька років значно збільшилася кількість туристів, що здійснюють закордонні поїздки. а також прямують за кордон з релігійно-пізнавальними цілями. Основні маршрути таких поїздок пролягли в Ізраїль, Італію, Грецію, Кіпр, Туреччину, Єгипет, Саудівську Аравію.

Аналіз останніх досліджень і публікацій. Важливість дослідження розвитку туристичної сорери та її значення проаналізована в працях іноземних та вітчизняних вчених. Наукові дослідження відображають багато проблем та особливостей туристичної сорери: особливості становлення туристичної індустрії в Україні - Шепелюк С.І., дослідження розвитку релігійного туризму - Биржакова М.Б., Кадацька Ю.А., Любіцева О.О., Мальська М.П., Масляк П.О., Романчук С.П., Сенін В.С., Яроцький П.Л., багатьма вченими проаналізовано загальний стан туристичної сорери - Оленічева Ю.О., Корнева Д.А.

Постановка завдання. Метою статті $\epsilon$ всебічна характеристика розвитку різних аспектів і видів туризму та регіональної особливості його розвитку в Україні. Завданням статті було дослідження сучасного стану і тенденцій розвитку туристичних потоків і окремих видів туризму в Україні: виявлення мети виїзду громадян України за кордон та географрії їх поїздок.

Виклад основного матеріалу дослідження. Щорічно Україну відвідує багато туристів і кількість їх постійно зростає. Інфрормація про виїзд і в"їзд туристів відображена в табл. 1.

Таблиця 1

Туристичні потоки України за видами туризму

тис. осіб

\begin{tabular}{|c|c|c|c|c|}
\hline \multirow{2}{*}{ Роки } & \multirow{2}{*}{ Разом } & \multicolumn{3}{|c|}{ У тому числі } \\
\cline { 3 - 5 } & & в'їзні & виїзні & внутрішні \\
\hline $\mathbf{2 0 0 0}$ & 2014 & 378 & 285 & 1351 \\
\hline $\mathbf{2 0 0 1}$ & 2175 & 416 & 271 & 1488 \\
\hline $\mathbf{2 0 0 8}$ & 3042 & 373 & 1282 & 1387 \\
\hline $\mathbf{2 0 1 3}$ & 3454 & 232 & 2519 & 703 \\
\hline $\mathbf{2 0 1 8}$ & 4557 & 76 & 4025 & 457 \\
\hline $\mathbf{2 0 1 9}$ & 6132 & 87 & 5525 & 520 \\
\hline Середня & $\mathbf{2 7 4 3}$ & $\mathbf{2 6 2}$ & $\mathbf{1 5 1 3}$ & $\mathbf{9 6 8}$ \\
\hline Структура & 100 & 10 & 55 & 35 \\
\hline
\end{tabular}

Джерело: [9]

Наведена табл. 1 скорочена за окремими роками, тому для наочності динаміки туристичних потоків надано їх графічне зображення на лінійній діаграмі (рис. 1).

Тенденція змін різних показників має різнонаправлений характер: кількість виїзних туристів стрімко зростає, а внутрішніх значно знижується, повільно знижується також кількість в"їзних туристів. В цілому загальна кількість всіх туристів України змінюється циклічно, маючи п'ятирічні цикли 3 вершинами у 2003, 2008, 2013 роках. 32017 року за рахунок виїзних туристів спостерігається різкий підйом загальної кількості туристів - в 1,6 рази у 2018 році і в 2,2 рази у 2019 році.

На загальну кількість туристів суттєво впливає структурний склад туристичних потоків (рис. 2).

Дані рис. 2 свідчать про суттєву зміну структури туристичних потоків у 2019 році проти середніх даних за аналізований дев'ятнадцятирічний період: в 10 разів скоротилась кількість в'їзних туристів, більш ніж у 4 рази знизилася кількість внутрішніх туристів, а кількість виїзних туристів майже 


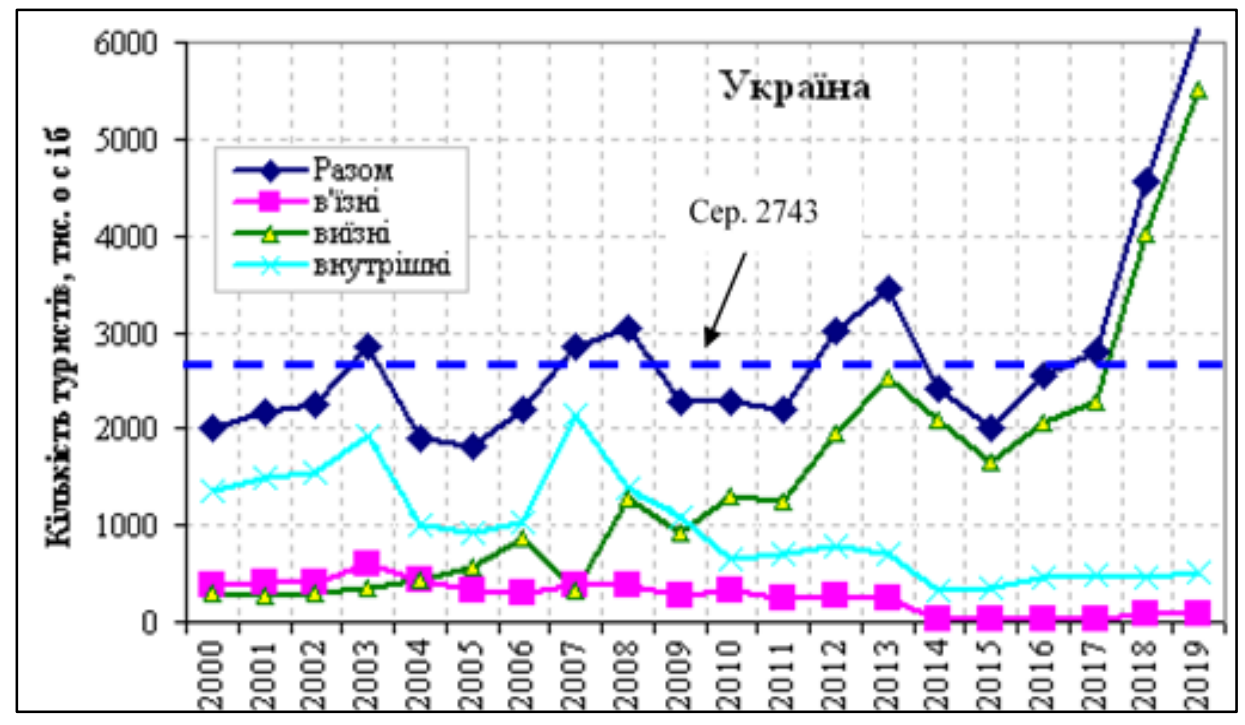

Рис. 1. Динаміка туристичних потоків України Джерело: власні дослідження
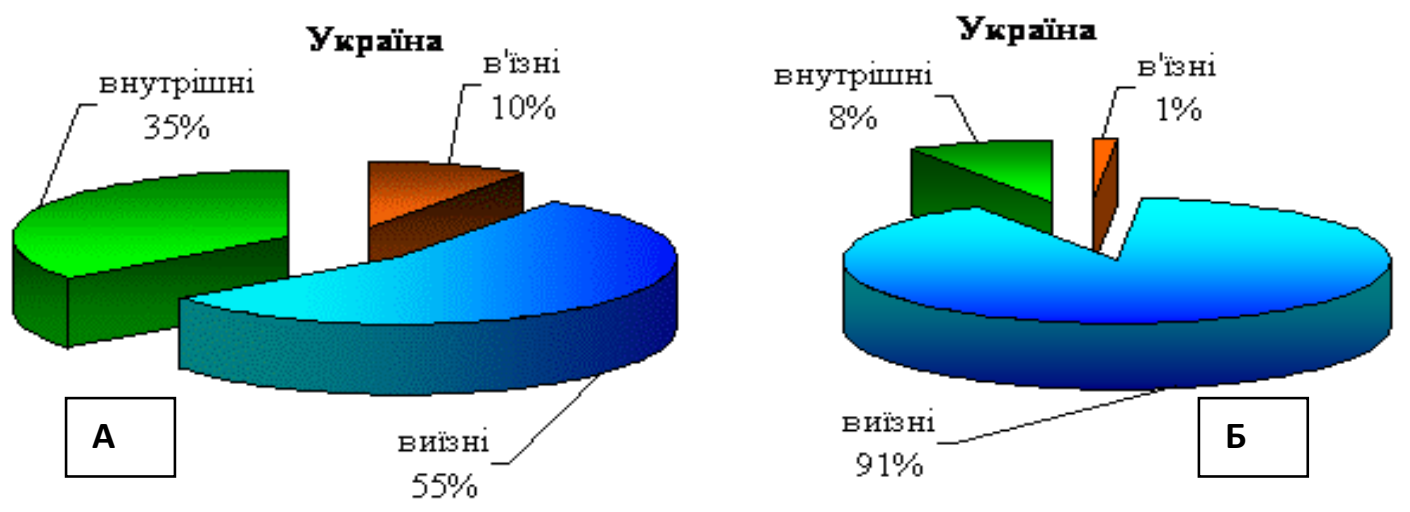

Рис. 2. Структура туристичних потоків України: А - в середньому за 2000-2019 рр.; Б - у 2019 році

Джерело: власні дослідження

вдвічі зросла і склала 91 \% від усіх туристів України. Такий стан розвитку туристичної галузі вважається негативним адже погіршується фрінансова складова держави.

Структурний склад туристів дуже відрізняється по зональному розподілу (рис. 3).

Так на заході в туристичному потоці переважають внутрішні туристи, в інших зонах виїзні, а з центральної зони майже всі туристі виїзжають за кордон.

Наочна картина регіонального складу турпотоків надається на рис. 4.

Турагенти майже всіх областей України зорієнтовані на закордонні тури. Виняток становлять лише декілька областей, в яких переважає внутрішній туризм: Івано-Франківська (91 \%), Вінницька (66 \%), Донецька (62 \%) та Сумська (57 \%). Серед усіх країн найбільшу популяр-

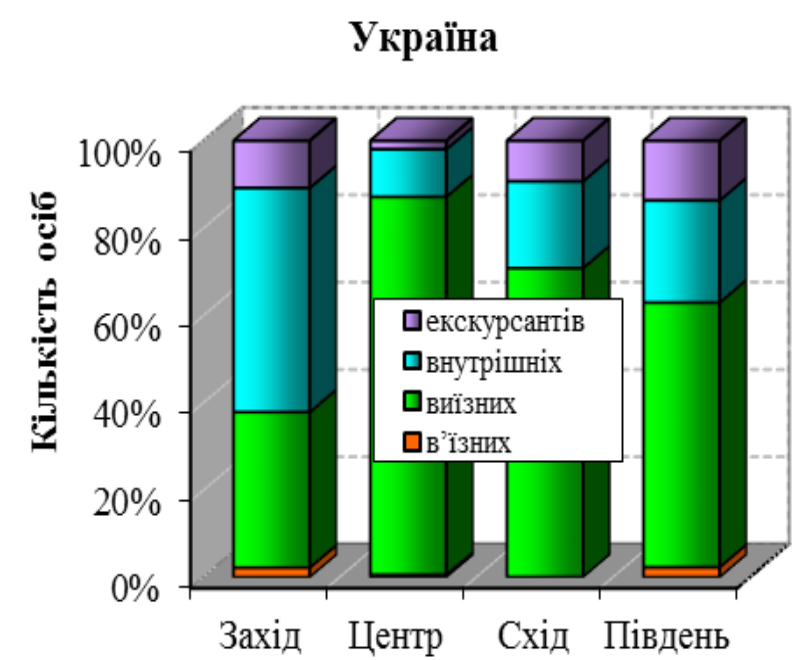

Рис. 3. Структура турпотоку у 2019 p. Джерело: власні дослідження 


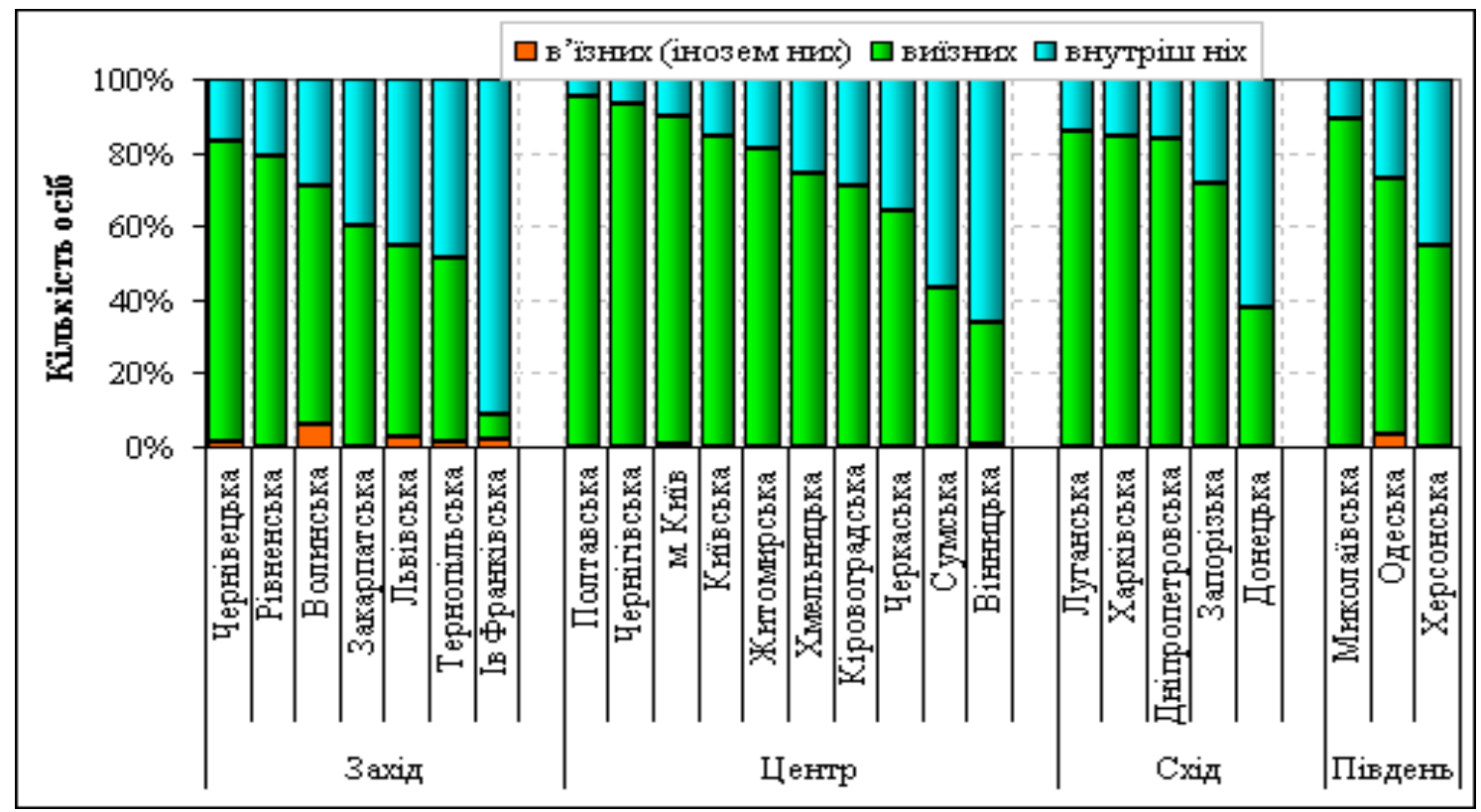

Рис. 4. Відсотковий склад турпотоків в регіонах України в 2019 році

Джерело: власні дослідження

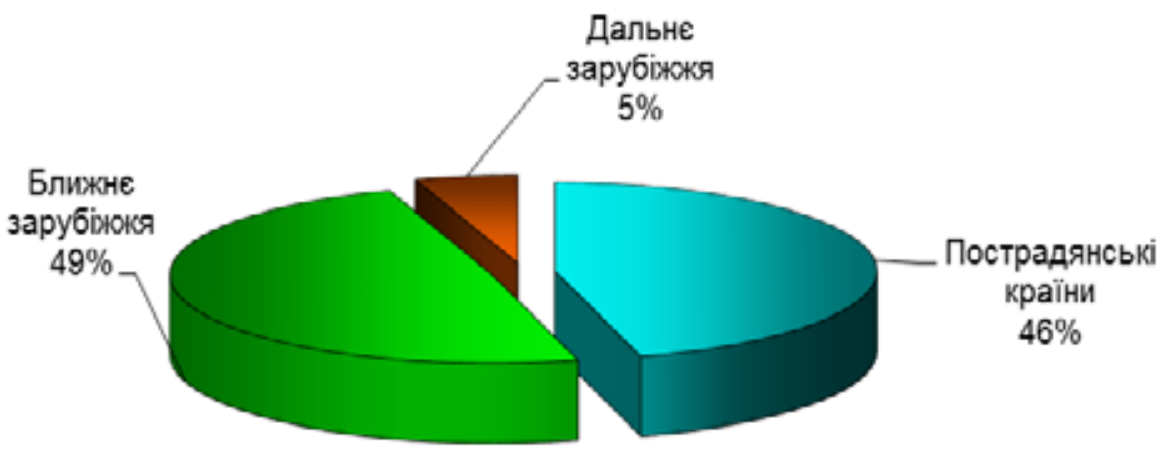

Рис. 5. Виїзд громадян України за кордон

Джерело: власні дослідження

ність серед громадян України, які виїзжають за кордон, має Ближнє зарубіжжя, тобто майже усі країни Європи і Близького Сходу (табл. 2).

3 огляду на рівень доходів населення на другому місці за прихильністю громадян Укра- їни $€$ пострадянські країни. I зовсім незначну питому вагу українці віддають Дальньому зарубіжжю. Структурний склад у кожній групі країн, до яких виїжджали громадяни України, надано на (рис. 5).

Таблиця 2

Виїзд громадян України за кордон за країнами, до яких вони виїжджали

\begin{tabular}{|c|c|c|c|c|}
\hline \multirow[b]{2}{*}{ Країни } & \multirow{2}{*}{$\begin{array}{c}\text { Кількість } \\
\text { громадян, } \\
\text { тис. осіб }\end{array}$} & \multicolumn{3}{|c|}{ \% до кількості } \\
\hline & & $\begin{array}{c}\text { приватна } \\
\text { поїздка }\end{array}$ & $\begin{array}{c}\text { організований } \\
\text { туризм }\end{array}$ & $\begin{array}{c}\text { службова } \\
\text { поїздка }\end{array}$ \\
\hline Усього & 5525 & 95,3 & 3,0 & 1,7 \\
\hline у тому числі & & & & \\
\hline Пострадянські країни & 2523 & 95,6 & 2,9 & 1,5 \\
\hline Ближнє зарубіжжя & 2716 & 95,0 & 3,0 & 2,0 \\
\hline Дальнє зарубіжжя & 285 & 95,3 & 3,8 & 0,9 \\
\hline
\end{tabular}

Джерело: [9] 

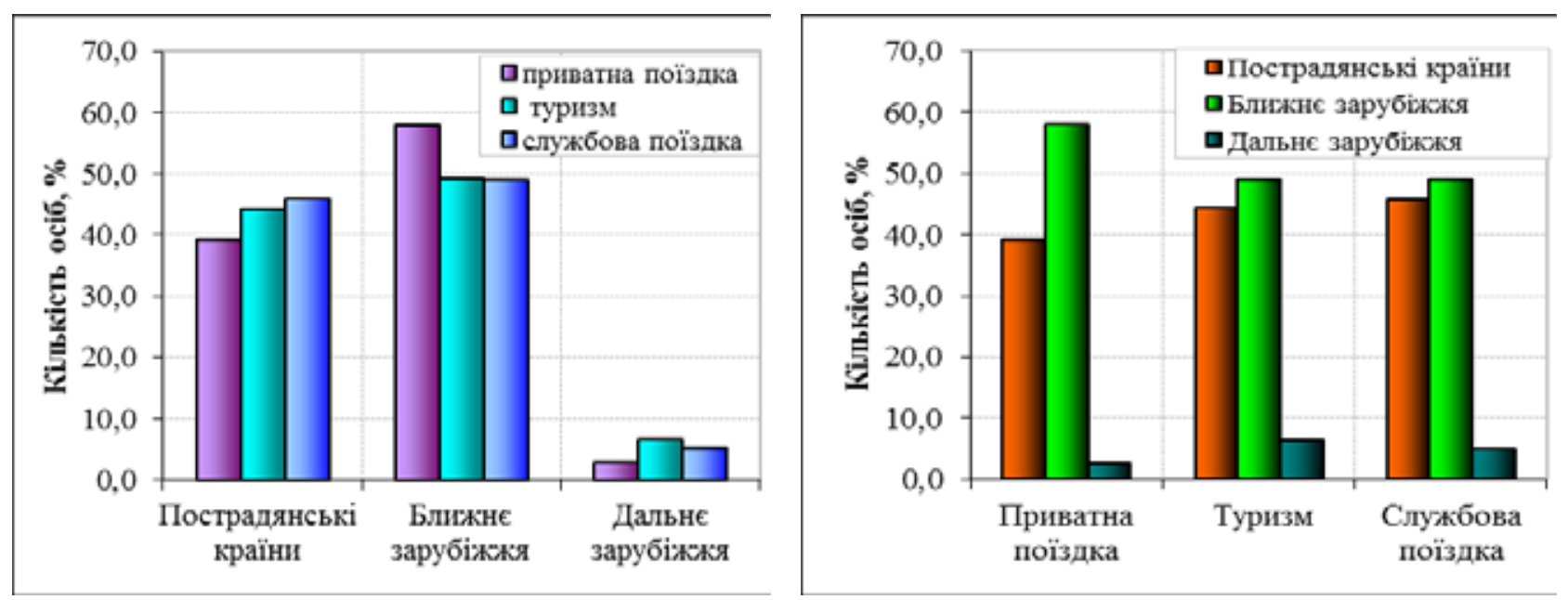

Рис. 6. Питома вага видів поїздок в загальному їх підсумку

Джерело: власні дослідження

Ближнє зарубіжжя і пострадянські країни складають основу (95 \%) зарубіжних поїздок. Найбільшу популярність серед пострадянських країн має Росія (61 \%), серед країни дальнього зарубіжжя - Італія (30\%), серед країни ближнього зарубіжжя - Польща (55 \%).

Мета поїздок громадян України за кордон різна, основними 3 них є: приватні поїздки, службові поїздки та організований туризм. В 2019 році у приватні поїздки, як свідчать дані табл. 1, виїжджали 95,3 \% (5525 тис.) українців, в організовані туристичні поїдки - всього 3,0% (165 тис.) і лише 1,7 \% (93 тис.) - у службові. Аналогічна картина спостерігається по всіх групах країн. Питома вага кожного виду поїздки до їх загальної кількості надана на рис. 6.

Ліва діаграма рис. 6 відображає особливість зарубіжних поїздок громадян України. Головною метою поїздок в пострадянські країни є службові поїздки (46 \%), в країни ближнього зарубіжжя - приватні поїздки (58 \%), в країни дальнього зарубіжжя - організований туризм (7 \%). Права діаграма ілюструє регіональний склад кожного виду поїздок. Основний відсоток громадян України здійснювали приватні поїздки в основному до країн ближнього зарубіжжя (58 \%), а до пострадянських країн - 39 \%. Майже однакова кількість громадян здійснювала туристичні поїздки до країн ближнього зарубіжжя (49 \%) та пострадянських країн (44 \%). Службові поїздки здійснювалися аналогічно в ті ж самі країни і в тих же самих кількостях (відповідно 49 \% і 46 \%).

У цілому в Україні близько 130 паломницьких відділів, служб, агентств, фрірм. Із загальної кількості (165 тис.) громадян організова- ного туризму 149 тис. мали путівки релігійних турагентств. Релігійний туризм в Україні має глибокі корені та тисячолітні традиції, тут поважають релігійні традиції і регулярно здійснюють паломництва з відвідуванням «святих місць» і релігійних центрів, а також приймають іноземних туристів. Метою ознайомлення туристів є визначні культові об'єкти своєї релігії та інші релігійно-культові традиції різних регіонів планети. Поєднання відвідувань релігійних об'єктів з цікавими та пізнавальними екскурсійними програмами розширює кругозір і сприяє більш глибшому сприйняттю духовної та історичної спадщини народів різних країн світу та розуміння суті їхньої релігії. Географрія пропонованих маршрутів охоплювала всю територію України та усіх країн Європи і Близького Сходу. Виїзд громадян України за кордон 3 релігійною метою ілюструє рис. 7.

Він складений з двох стовпчикових діаграм різного масштабу шкал. Розглядаючи ці дані, можна констатувати, що кількість прочан, які виїжджають в пострадянські країни в два і більше разів вища проти інших зарубіжних країн.

Паломницький потік в Росію до її лавр, монастирів і чудотворних ікон $€$ найбільшим, адже значна частина православних громадян України підпорядкована Московському патріархату. В Росії налічується 313 монастирів, перебуває 8 місць поховань святих угодників

Паломництво розповсюджено практично у всіх релігіях. Найвідоміші християнські релігійно-паломницькі святині сконцентровані переважно в Європі - Греція, Італія, Кіпр, Франція, Німеччина, Румунія, у тому числі й в Україні, а також в Азії - Ізраїль, Туреччина, Єгипет, Саудівська Аравія, Індія, Китай, Тибет. 

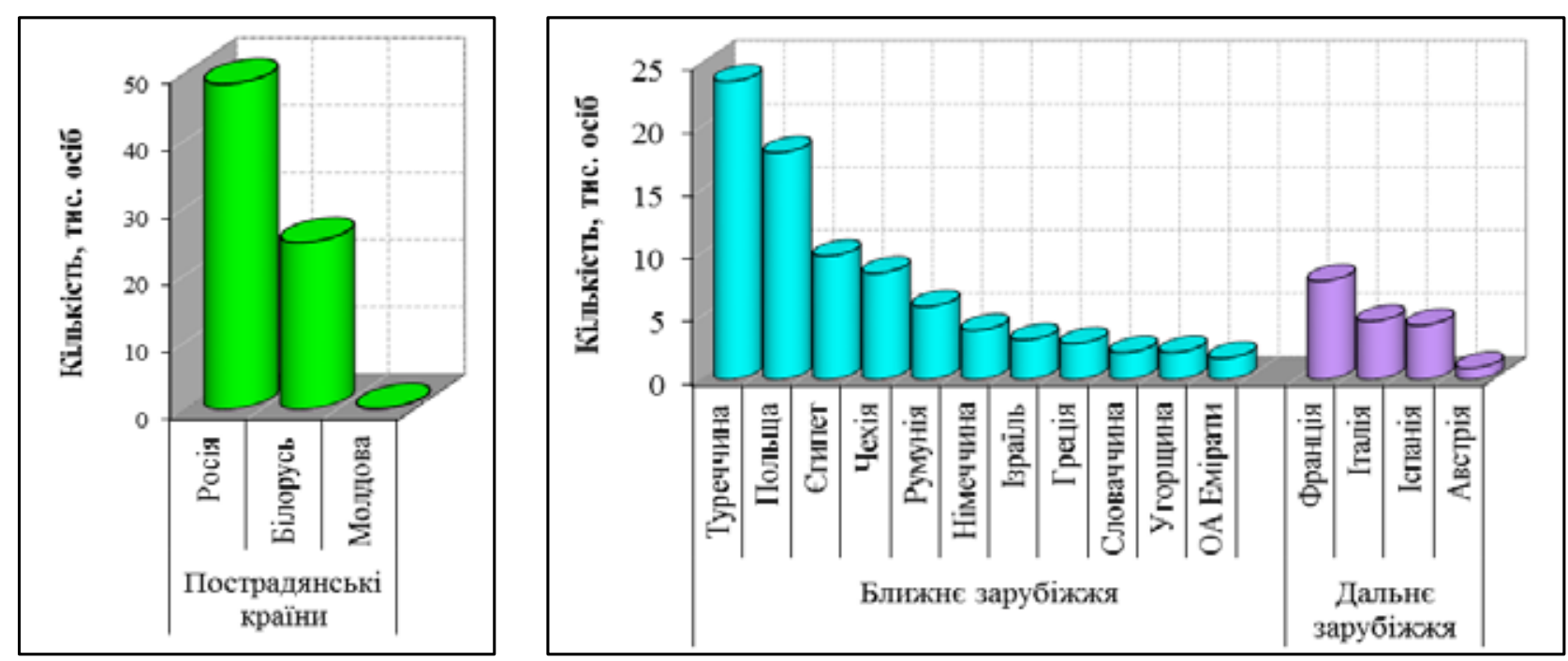

Рис. 7. Виїзд громадян України за кордон з релігійною метою

Джерело: власні дослідження

Християнська Європа є головним світовим регіоном паломництва, невичерпним джерелом подорожей та духовних відкриттів: славиться стародавніми містами 3 величними храмами і шанованими святинями. Основними світовими місцями паломництва $є$ : у християн: Віфрлеєм, Єрусалим, Назарет, річка Йордан та інші місцевості, пов'язані 3 Христом, апостолами, Пресвятою Богородицею. Українці, здійснюють також паломництво до святинь Ватикану, Венеції, Люрду, Риму, Парижу тощо. Значна частина українців, відпочиваючих в Туреччині і Греції, здійснює там релігійно-пізнавальні екскурсії по святих християнських місць, де діяло багато апостолів і святих: поїздки в Міру (Демре) і Ефес в Туреччині, на Афрон в Греції.

Висновки. Щорічно Україну відвідує багато туристів і кількість їх постійно зростає. Тенденції розвитку окремих видів туризму мають різнонаправлений характер: кількість виїзних туристів стрімко зростає, внутрішніх - значно знижується, в'їзних - повільно знижується. Загальна кількість всіх туристів України змінюється циклічно, маючи п'ятирічні цикли з вершинами у 2003, 2008, 2013 роках. За рахунок виїзних туристів спостерігається різкий підйом загальної кількості туристів - в 1,6 рази, у 2018 році і в 2,2 рази у 2019 році. Структурний склад туристів не є однорідним: має потоки внутрішніх, в"їзних і виїзних туристів, який дуже відрізняється по зонах України. Основу зарубіжних поїздок складають туристи пострадянських країн і Ближнього зарубіжжя. Найбільшу популярність серед пострадянських країн має Росія, серед країни ближнього зарубіжжя Польща, серед країни дальнього зарубіжжя Італія (30\%). Мета поїздок громадян України за кордон різна, основними з них є: приватні й службові поїздки та організований туризм. Геограсрія закордонних маршрутів охоплювала усі країн Європи і Близького Сходу.

\section{СПИСОК ВИКОРИСТАНИХ ДЖЕРЕЛ:}

1. Івченко А. Україна. Путівник. Київ : Картограсрія, 2007. 640 с.

2. Економічний аналіз туристичних підприємств : підручник / В. В. Тарасова та ін. Житомир : вид-во ЖHAEУ, 2019. $371 \mathrm{c}$.

3. Любіцева О.О., Романчук С.П. Паломництво та релігійний туризм : навч. посібник. Київ : Альтерпрес, 2011. $416 \mathrm{c}$.

4. Мальська М.П., Антонюк Н.В., Ганич Н.М. Міжнародний туризм і сфера послуг. Київ : Знання, 2008. 661 с.

5. Міністерство культури та інсрормаційної політики України : веб-сайт. URL: http://www.irs.in.ua (дата звернення: 14.12.2020).

6. Основи організації наукових досліджень в туризмознавстві : підручник / В. В. Тарасова та ін. Житомир : вид-ць О.О. Євенок, 2018. 454 с.

7. Інсрормаційний звіт Мінкультури "Про стан і тенденції розвитку релігійної ситуації та державно-конфресійних відносин в Україні за 2012 рік" : IPC : веб-сайт. URL: https://irs.in.ua/ua/informaciinii-zvit-minkulturi- 
pro-stan-i-tendenciji-rozvitku-religiinoji-situaciji-ta-derzhavno-konfesiinih-vidnosin-v-ukrajini-za-2012-rik (дата звернення: 22.12.2020).

8. Релігія і влада в Україні: проблеми взаємовідносин : інформаційно-аналітичні матеріали. Київ : Центр Разумкова, 2013. 76 с.

9. Туристична діяльність в Україні у 2020 році : Статистичний бюлетень. Київ : Державна служба статистики України, 2020. 76 c. URL: http://www.ukrstat.gov.ua/ (дата звернення: 22.12.2020).

10. Силантьева М. В. Духовный смысл православного паломничества в эпоху глобализации : Сб. науч. статей: Паломничество и религиозный туризм: разнообразие интерпретаций. Владимир, 2012. С. 150-173.

\section{REFERENCES:}

1. Ivchenko A. (2007) Ukraina. Putivnyk [Ukraine. Guidebook]. Kyiv: Kartohrafiia, 640 p. (in Ukrainian)

2. Ekonomichnyi analiz turystychnykh pidpryiemstv: pidruchnyk (2019) [Economic analysis of tourism enterprises] / V.V. Tarasova ta in. Zhytomyr: vyd-vo ZhNAEU, 371 p. (in Ukrainian)

3. Liubitseva O.O., Romanchuk S.P. (2011) Palomnytstvo ta relihiinyi turyzm [Pilgrimage and religious tourism]: navch. posibnyk. Kyiv: Alterpres, 416 p. (in Ukrainian)

4. Malska M.P., Antoniuk N.V., Hanych N.M. (2008) Mizhnarodnyi turyzm i sfera posluh [International tourism and services]. Kyiv: Znannia, 661 p. (in Ukrainian)

5. Ministerstvo kultury ta informatsiinoi polityky Ukrainy [Ministry of Culture and Information Policy of Ukraine]: veb-sait. URL: http://www.irs.in.ua (accessed 14 December 2020).

6. Osnovy orhanizatsii naukovykh doslidzhen $v$ turyzmoznavstvi [Fundamentals of the organization of scientific research in tourism]: pidruchnyk / V.V. Tarasova ta in. Zhytomyr: vyd-ts O.O. Yevenok, 2018. 454 p. (in Ukrainian)

7. Informatsiinyi zvit Minkultury "Pro stan i tendentsii rozvytku relihiinoi sytuatsii ta derzhavno-konfesiinykh vidnosyn v Ukraini za 2012 rik" ["On the state and trends of the religious situation and state-confessional relations in Ukraine in 2012"]: IRS: veb-sait. URL: https://irs.in.ua/ua/informaciinii-zvit-minkulturi-pro-stan-i-tendenciji-rozvitku-religiinoji-situaciji-ta-derzhavno-konfesiinih-vidnosin-v-ukrajini-za-2012-rik (accessed 22 December 2020).

8. Relihiia i vlada v Ukraini: problemy vzaiemovidnosyn [Religion and power in Ukraine: problems of relations]: informatsiino-analitychni materialy. Kyiv: Tsentr Razumkova, 2013. 76 p.

9. Turystychna diialnist v Ukraini u 2020 rotsi [Tourist activity in Ukraine in 2020]: Statystychnyi biuleten. Kyiv: Derzhavna sluzhba statystyky Ukrainy, 2020. 76 p. URL: http://www.ukrstat.gov.ua (accessed 22 December 2020).

10. Sylanteva M.V. (2012) Dukhovnyi smysl pravoslavnoho palomnychestva v epokhu hlobalyzatsyy [The spiritual meaning of Orthodox pilgrimage in the era of globalization]: Sb. nauch. statei: Palomnychestvo y relyhyoznyi turyzm: raznoobrazye ynterpretatsyi. Vladymyr, pp. 150-173. (in Russian) 